\title{
Towards Context-Specific Directors' Duties and Enforcement Mechanisms in the Banking Sector?
}

\author{
Wasima Khan*
}

\section{Abstract}

The global financial crisis gives reason to revisit the debate on directors' duties in corporate law, mainly with regard to the context of banks. This article explores the need, rationale and the potential for the introduction of context-specific directors' duties and enforcement mechanisms in the banking sector in the Netherlands from a comparative perspective.

Chiefly, two legal strategies can be derived from the postcrisis developments and calls for legal reforms for the need and rationale to sharpen directors' duties in the context of the banking sector in order to meet societal demands. The two strategies consist in shifting the scope of directors' duties (i) towards clients' interests and (ii) towards the public interest.

Subsequently, this article explores the potential for contextspecific directors' duties and accompanying enforcement mechanisms. Firstly, it is argued that the current legal framework allows for the judicial development -specific approach. Secondly, such context-specific directors' duties should be enforced through public-enforcement mechanisms to enhance the accountability of bank directors towards the public interest but currently there are too much barriers for implementation in practice.

In conclusion, this article argues that there is indeed a need, rationale and potential for context-specific directors' duties; yet there are several major obstacles for the implementation of accompanying public-enforcement mechanisms. As a result, the introduction of context-specific directors' duties in the banking sector may as yet entail nothing more than wishful thinking because it will merely end in toothless ambitions if the lack of accompanying enforcement mechanisms remains intact.

Keywords: banking sector, directors' duties, financial crisis, context-specific doctrines, public enforcement

The goal of the private sector cannot be only profit; it must also be to add value, create jobs, develop the new ideas that drive an economy formard. Vested interests

* PhD Candidate at the Erasmus School of Law, Erasmus University Rotterdam. The author wishes to express her gratitude for valuable comments on an earlier draft of this article from Prof. Vino Timmerman and Prof. Bastiaan F. Assink at the Erasmus School of Law, Erasmus University Rotterdam, as well as the Journal's editors and peer reviewers. Any errors remain those of the author. and arbitrage typically hinder the accountability principle. One has in mind the financial sector, which turned out to be insufficiently accountable - to its clients, its shareholders, and to society in general. As we all know, the global economic crisis mas, in many respects, a governance crisis originating in the financial sector. ${ }^{1}$

\section{Introduction}

1.1 Corporate Governance in the Banking Sector The recent global financial crisis gives rise to a wide reflection on the functioning of corporate governance ${ }^{2}$ in banks and other financial institutions. ${ }^{3}$ In hindsight, it seems to have become clear that directors of financial institutions failed to prudently govern and oversee the management and business affairs of their companies when they approved too risky strategies. ${ }^{4}$ It is also argued that the crisis has revealed that the interests of directors did not necessarily tie in with the long-term interests of the financial institution they were managing and that the interests of certain stakeholders, such as depositors or employees, have not been sufficiently taken into account. ${ }^{5}$ If these claims are deemed to be valid,

1. C. Lagarde, A New Global Economy for a New Generation, speech at the World Economic Forum 2013 on 23 January 2013 in Davos, Switzerland. See <http://www.imf.org/external/np/speeches/2013/012313 .htm> (last visited 14 Oct. 2013)

2. There is no univocal definition of the comprehensive phrase corporate governance. The OECD Principles of Corporate Governance 2004 describe this concept in the following manner: 'Corporate governance involves a set of relationships between a company's management, its board, its shareholders and other stakeholders. Corporate governance also provides the structure through which the objectives of the company are set, and the means of attaining those objectives and monitoring performance are determined'. Corporate law and governance are highly interrelated; corporate law sets the conditions for corporate governance.

3. See, e.g., European Commission (2010), Green Paper on corporate governance in financial institutions and remuneration policies, COM (2010) 284 final.

4. Group of Thirty, Toward Effective Governance of Financial Institutions (2012), at 5. See also A. Turner, The Turner Review: Regulatory Response to the Global Banking Crisis (2009) (mentioning that the failure of banks to manage risks was one of the proximate causes of the financial crisis).

5. European Commission (2010a), Corporate Governance in Financial Institutions: Lessons to be drawn from the current financial crisis, best practices, SEC(2010) 669, at 6 . 
an urgent follow-up question is to what extent we can hold directors accountable for such detrimental actions. In order to evaluate the accountability of bank directors in the aftermath of the financial crisis, it is essential to recognize that banks differ from non-financial companies, mainly because of the crucial functions of financial intermediation ${ }^{6}$ and central capital allocation ${ }^{7}$ they fulfil for individuals and companies serving both the society and the economy as a whole. This specific role emphasizes the important position of a wide range of stakeholders in the corporate governance of banks since failures of banks and other financial institutions could have systemic consequences affecting society as a whole. ${ }^{8}$ This notion has risen prominently to the surface during the recent financial crisis. As such, companies in the banking sector have a social function in the economy resulting in a dual responsibility, not only towards the company and its shareholders but also to the society as a whole. The crisis has revealed that when these responsibilities conflict, directors should be cautious in making trade-offs that might neglect the interest of the society.

\subsection{Post-Crisis Measures for Reforms in Corporate Governance}

In recognition of the particular function of banks and other financial institutions, context-specific corporate governance practices have been developed in the financial sector. In the post-crisis era, this development has experienced a mushroom growth by means of a rapidly increasing number of domestic self-regulatory corporate governance codes for the financial sector, i.e. banks and other financial institutions, in various countries worldwide 9 aiming to provide principles for responsible conduct. Many of these codes are based on international standards established by the Basel Committee on Banking Supervision setting out expectations of banking supervisors in relation to the minimum standards for corporate governance of their licensees. These codes

6. Basel Committee on Banking Supervision, Enhancing Corporate Governance for Banking Organisations (2006), at 1.

7. C.M. Bruner, 'Conceptions of Corporate Purpose in Post-Crisis Financial Firms', 36 Seattle U. L. Rev., at 527 (2013); R. Levine (2004), The Corporate Governance of Banks: A Concise Discussion of Concepts and Evidence, World Bank Policy Research Working Paper No. 3404, available at SSRN: <http://ssrn.com/abstract=625281> (last visited 14 Oct. 2013).

8. OECD (2009), Corporate Governance and the Financial Crisis: Key Findings and Main Messages.

9. See, e.g., Central Bank of Jordan (2007), Corporate Governance Code for Banks in Jordan, Qatar Central Bank (2008), Corporate Governance Guidelines for Banks and Financial Institutions, Dutch Banking Association (2009) The Banking Code, Walker Committee (2009), A Review of Corporate Governance in UK banks and other financial industry entities, Association of the Luxembourg Fund Industry (2009), ALFI Code of Conduct for Luxembourg Investment Funds, Association of Banks of Georgia (2009), Corporate Governance Code for Commercial Banks, Central Bank of Ireland (2010), Corporate Governance Code for Credit Institutions and Insurance Undertakings, Monetary Authority of Singapore (2010), Guidelines on corporate governance for banks, financial holding companies and direct insurers which are incorporated in Singapore, Guernsey Financial Services Commission (2011), Finance sector code of corporate governance, The Clearing House Association (2012), Guiding Principles for Banking Organization Corporate Governance, Central Bank of Barbados (2013), Corporate Governance Guideline. contain best practices and detailed recommendations that may be used as guidelines for banks and other financial institutions to arrange their corporate governance practices. The main benefit of such codes is that they provide directors with guidance on their corporate governance structures without the downside risk of actual personal legal liability. It remains questionable, however, whether we can rely on self-regulation to solve the crisis regarding corporate governance in the financial sector.

Besides self-regulatory codes of corporate governance (soft law) for banks and other financial institutions, an important subject of discussion remains whether reforms to directors' duties in the corporate legal framework may be useful to align the accountability of directors of banks with their dual role towards shareholders and the society effectively. ${ }^{10}$ In the Netherlands, this discussion would be mostly concerned with the interpretation and enforcement of the directors' duty to protect the interests of the company in the specific context of banks. The general directors' duty to protect the interests of the company and the interests of those involved is implemented in Dutch statutory corporate law. Legal provisions stipulate directors to act in the interest of the company and its affiliated enterprise in Section 2:129, paragraph 5 (public companies) and Section 2:239, paragraph 5 (closed companies) of the Dutch Civil Code. Does this general duty suffice to provide an effective enforcement mechanism to hold bank directors accountable in the aftermath of the financial crisis? If so, are bank directors actually held accountable? If not, are there perhaps alternatives to align the accountability of bank directors with the needs of the society?

\subsection{Outline}

This article explores the need and rationale as well as the potential for the introduction of specific directors' duties with accompanying enforcement mechanisms in the context of the banking sector. I aim to put forward the notion that context-specific duties in the banking sector would fit in with the practice of post-crisis developments as well as the judicial development of contextspecific sub-doctrines to open-textured directors' duties. Subsequently, I question whether such contextspecific directors' duties can be accompanied with public-enforcement mechanisms in order to ensure possibilities for the public to hold bank directors accountable. Firstly, before delving further into the feasibility of context-specific directors' duties for the banking sector, a short background is provided of the current Dutch corporate law system with regard to the general directors' duty to act in the interest of the corporation and its

10. See, e.g., R. Anderson (2009), Risk Management \& Corporate Governance (report prepared for the OECD), at 24-25, 37, with a recommendation to the OECD that in the case of organisations that have a broad societal impact and who therefore owe a duty of care to society at large, directors should owe a new legal duty to discharge their corporate governance responsibilities with due and diligent care, in order to enforce a change of culture in the banking industry as this is an industry that contributes significantly to the proper functioning of the economic system. 
affiliated enterprise as an open-textured legal concept (Section 2). This general directors' duty is concerned with the key obligation for directors to balance the interests of various corporate stakeholders while discharging directors' responsibilities. Secondly, the need and rationale for implementing a sector-specific approach in the context of banks and other financial institutions will be considered (Section 3) by providing a comparative analysis of post-crisis proposals for legal reforms in the Netherlands, the United Kingdom and Europe, which suggest to shift the scope of directors' duties to clients' interests and by examining post-crisis developments highlighting the particular nature of corporate governance in the banking sector arising from the social function of banks, which suggest to shift the scope of directors' duties to the public interest. Thirdly, the potential for context-specific directors' duties will be explored (Section 4) by examining the process of the judicial creation of context-specific directors' duties as sub-doctrines to general directors' duties. Fourthly, the potential for the introduction of accompanying publicenforcement mechanisms in the form of criminal liability will be explored (Section 5) to enhance the accountability of directors to sector-specific directors' duties. In conclusion, a summary is provided of the main findings of this article.

\subsection{Limitations}

Potential changes to the interpretation and enforcement of directors' duties are merely one aspect of reforming the corporate governance of banks. This aspect cannot be viewed isolated from other proposed measures to tackle the past failures in the financial sector. Although not the main focus of this article, it is worthwhile to mention these other proposals briefly as they would inevitably have an impact on the wider corporate governance system and as such are very much interrelated to the functioning of directors' duties. Other measures and policy recommendations for reforms in the corporate governance of banks include - inter alia - proposals to curb excessive board remuneration and compensation packages, to align the performance standards of senior executives with the bank's long-term objectives and strategy $^{11}$ in order to discourage excessive short-term risk-taking, to include stakeholders such as a regulator and debt holders in the board structure, ${ }^{12}$ to educate independent board members in the operational details and complex products of financial institutions, ${ }^{13}$ or to change the organisational structure of banks and reallocate risks by means of 'ring-fencing' banks, i.e. legally separating certain risky assets from retail banking operations.

11. Basel Committee on Banking Supervision (2010a), Principles for Enhancing Corporate Governance, Basel: BIS 2010, at 9, available at: <http://www.bis.org/publ/bcbs176.pdf> (last visited 14 Oct. 2013).

12. V.V. Acharya, J.N. Carpenter, X. Gabaix, X., et al., Corporate Governance in the Modern Financial Sector, in V. Acharya, and M. Richardson (eds.), Restoring Financial Stability: How to Repair a Failed System (2009), at $185-196$

13. Id
Furthermore, the effects of legislative measures are limited from a behavioural point of view as this perspective propagates that not all behaviour can be captured by regulation. ${ }^{14}$ Extra-legal and non-quantifiable forces such as moral values and culture play an important role in shaping the behavioural patterns of directors because they 'drive people to do the right thing even when no one is looking'. ${ }^{15}$ The Dutch Central Bank (DNB) has discerned the importance of behaviour and culture in financial institutions and stated that there is a lack of clear consideration of various stakeholders' interests within the financial sector. ${ }^{16}$ The DNB mentions the balancing of interests as one of the seven elements that lead the way to a culture of integrity. Although it is recognized that such extra-legal indicators play an important role to create a culture of legal compliance, this article is limited to the view from law and will not delve further into the behavioural perspective.

\section{General Directors' Duties: An Open-Textured Legal Concept}

\subsection{The Open Texture of General Directors' Duties}

General directors' duties have an open-textured character in both common law and civil law jurisdictions. Directors' duties in English common law countries are based on a fiduciary relationship resulting in fiduciary directors' duties covering a legal relationship of trust and confidence. Fiduciary standards traditionally stem from the English legal system where they are viewed as the mainstay of the relationship between directors and the company and its shareholders. Fiduciary directors' duties aim to settle the tensions that come with the separation of control and ownership in companies, arising from the delegation of control to directors and the residual ownership of shareholders. ${ }^{17}$ These duties are regarded to be an important legal protection device with a primary - not a sole - responsibility towards shareholders when conflicts of interests between directors and the company arise. In the Netherlands, statutory law engages in setting legal standards of conduct for directors. These statutory directors' duties - alike their common law counterparts - arouse legal uncertainty because they are to be characterized as open-textured legal standards

14. See, e.g., R. Tomasic, "Beyond "Light Touch" Regulation of British banks after the Financial Crisis' in I. MacNeil and P.J. O'Brien (eds.), The Future of Financial Regulation (2010), at 103-122, 103 (mentioning the power of market euphoria and perverse incentives as behavioural factors).

15. Group of Thirty (2012), above n. 4, at 15.

16. DNB (2009). De 7 Elementen van een Integere Cultuur: Beleidsvisie en aanpak gedrag en cultuur bij financiële ondernemingen 2010-2014 (The 7 Elements of a Sound Culture: Policy Outlook and Tackling Behavior and Culture at Financial Enterprises), November 2009.

17. M.M. Blair, Ownership and Control: Rethinking Corporate Governance for the Twenty-First Century (1995), at 56. 
of conduct, which are essentially context-dependent in most cases.

Dutch corporate law mainly recognizes two general directors' duties in the form of open-textured standards of conduct. These directors' duties are codified in Section 2:8 Dutch Civil Code (duty to act in reasonableness and fairness) and Section 2:9 Dutch Civil Code (duty of proper performance) for companies. Additionally, Section 2:129, paragraph 5 Dutch Civil Code (for public companies) and Section 2:239, paragraph 5 Dutch Civil Code (for private companies) describes how directors are regarded to act in the interest of the company and its affiliated enterprise in the fulfilment of their duties. This duty might provide more clarification on the corporate objectives and the scope of beneficiaries to be taken into account when directors fulfil their directors' duties.

Section 2:8 Dutch Civil Code is at the heart of Dutch corporate law dealing with the internal affairs of the company. This provision provides that every legal person such as a company, and those involved with its organisation by statutory law and articles of association, have a duty to act in reasonableness and fairness towards each other. ${ }^{18}$ Furthermore, the standard provides that the terms of reasonableness and fairness may require looking beyond the law, common practice, bylaws, regulations, or resolutions, when considering the circumstances of the case. ${ }^{19}$ The wide span of the term reasonableness and fairness envelops a comprehensive legal concept. This notion includes the consideration of generally prevailing legal conceptions in the Netherlands ${ }^{20}$ as well as the social and personal interests involved in the given situation. ${ }^{21}$ This standard requires of the company and those involved to exercise care in their conduct, which implies that in defending their own interests each party should at all times be co-guided by the legitimate interests of others in the company and after this consideration should spare them if their interests would be disproportionally harmed. ${ }^{22}$ The effectuation of this duty of care varies depending on the circumstances of the case.

According to Section 2:9 Dutch Civil Code, every director owes a duty of proper performance to the company. There is not a single and clear definition of the term proper performance. Similar to Section 2:8 Dutch Civil Code, this is an open-textured standard. Directors rely on case law to gain clarity on the interpretation of this standard.

18. Sec. 2:8, para. 1 Dutch Civil Code.

19. Sec. 2:8, para. 2 Dutch Civil Code.

20. E.g., the best practices of the Dutch Corporate Governance Code, see Dutch Supreme Court 9 July 2010, NJ 2010, 544 (ASMI).

21. Sec. 3:12 Dutch Civil Code, Dutch Supreme Court 1 March 2002, NJ 2002, 296 (Zwagerman Beheer).

22. More in general, this standard emphasizes the co-dependency of those involved with the company, thereby coinciding with a mode of life: '[s]omehow we're caught in an inescapable network of mutuality tied in a single garment of destiny. Whatever affects one directly affects all indirectly. (...) This is the interrelated structure of reality'. M.L. King Jr., Dr. Martin Luther King's 1963 WMU Speech Found (1963), 18 December 1963, available at: <http://www.wmich.edu/ ulib/archives/mlk/ transcription.html> (last visited 14 Oct. 2013).
2.2 The Duty to Act in the Interest of the Company and Its Affiliated Enterprise

Whilst discharging their general duties, directors are required by statutory law to take into account the duty to act in the interest of the company and its affiliated enterprise. ${ }^{23}$ Neither courts nor legal scholars have as yet indicated a uniform definition of what constitutes the interest of the company. ${ }^{24} \mathrm{I}$ argue that the substantive interpretation of this open-textured duty can be defined further dynamically in various situations and circumstances by (1) viewing which corporate objective is to be pursued by directors in the given context, while (2) specifying which corporate stakeholders are to be regarded as beneficiaries with regard to that corporate objective.

The currently prevailing notion regarding the substantive meaning of this duty merely recognizes an allembracing responsibility for directors to take a nonspecified wide range of stakeholders' interests (beneficiaries) into account for the continuity of the company (corporate objective) in the fulfilment of their duties. This notion does not pursue the context-sensitivity of the duty in greater depth and as such the contents of this duty remain to be rather hollow and static. The one thing that might be clearly derived from this interpretation is that this directors' duty is not primarily geared towards the interests of shareholders but has a pluralist basis requiring directors to act in the interests of a wide range of stakeholders as beneficiaries. ${ }^{25}$ Yet more recently, even the scope of this heterogeneous model seems to have become uncertain now heading in favour of a prevailing monolithic pursuit of long-term shareholder value with an increased focus on shareholders' interests. ${ }^{26}$ The shifting paradigm is expressed in the revised Dutch Corporate Governance Code 2008 for listed public companies, where it is stated that

The Code is based on the principle accepted in the Netherlands that a company is a long-term alliance between the various parties involved in the company. The stakeholders are the groups and individuals who,

23. Sec. 2:129, para. 5 (public companies) and Sec. 2:139, para. 5 (private companies) of the Dutch Civil Code. Prior to the implementation of this legal provision, Dutch corporate case law recognized this notion in the cases Dutch Supreme Court 1 April 1949, NJ 1949, at 465 (Doetinchemse IJzergieterij) and Dutch Supreme Court 4 January 1963, NJ 1964, at 434 (Scholten's Aardappelmeelfabrieken), where it was decided that the directors were allowed to issue shares against the wish of shareholders if this action served the interest of the company.

24. B.F. Assink, De Januskop van het ondernemingsrecht: over faciliëring en regulering van het ondernemerschap (2010) (The Double-Faced Head of Corporate Law: On Facilitation and Regulation of Entrepreneurship), (inaugural lecture Rotterdam), at 36 et seq.

25. Timmerman mentions that the plurality of interests pursued and weighed against each other in a company by directors is one of the prevailing principles of Dutch company law, see L. Timmerman, 'Principles of Prevailing Dutch Company Law', 11 European Business Organization Law Review (EBOR) 4, at 609-627 (2010), also available at SSRN: <http:// ssrn.com/abstract $=1503943>$ (last visited 14 Oct. 2013).

26. See also L. Timmerman (2010) (defending the approach of 'enlightened shareholder value' similar to Sec. 172 UK Companies Act 2006 where principally the long term interests of shareholders prevail while other stakeholders' interests may also be taken into account when these interests are likely to be neglected disproportionally). 
directly or indirectly, influence - or are influenced by - the attainment of the company's objects: i.e. employees, shareholders and other lenders, suppliers, customers, the public sector and civil society. The management board and the supervisory board have overall responsibility for weighing up these interests, generally with a view to ensuring the continuity of the enterprise, while the company endeavours to create long-term shareholder value. ${ }^{27}$

From this definition, it becomes clear that the twin corporate objectives of continuity along with long-term shareholder value are to be pursued by directors while at the same time having regard to a wide range of other stakeholders' interests. ${ }^{28}$ The validity of 'long-term shareholder value' as a corporate objective for the interpretation of this duty has as yet not been explicitly verified by courts.

Pursuing this question in greater depth, long-term shareholder value seems to be a more univalent objective for directors to pursue as the stress predominantly falls on one stakeholder group - i.e. the shareholder body when speaking of shareholder value. In practice, this provides directors a single valued metric thereby preventing a deadlock regarding the trade-off between the interests of various stakeholders in decision-making procedures. Yet the notion of shareholder value viewed apart is not as uniform as it may seem at first glance. The underlying interests of the shareholder body of large public companies with a dispersed ownership structure may be divided by various individual shareholders with conflicting underlying goals. ${ }^{29}$

Moreover, attempting to define and carry out the longterm perspective remains an ambiguous and impracticable task for directors because of various reasons: (1) Several commentators agree that companies should be managed for the long term, ${ }^{30}$ but it is rather unclear how to make a distinction between the consequences for the short term on the one hand and the long-term on the other hand while pursuing certain major business transactions. The law does not draw a sharp line with regard to the time horizon of corporate objectives. (2) In practice, directors may be inclined to make decisions accommodated by discretionary powers - with a visible

27. Dutch Corporate Governance Code 2008, Preamble, No. 7.

28. In comparison with the UK, this definition is in line with the general directors' duty to promote the success of the company as formulated in Sec. 172 UK Companies Act 2006

29. See, e.g., I. Anabtawi \& L. Stout, 'Fiduciary Duties for Activist Shareholders', 60 Stan. L. Rev. 5, at 1255, 1287 (2008); J.E. Fisch, 'Measuring Efficiency in Corporate Law: The Role of Shareholder Primacy', $31 \mathrm{~J}$. Corp. L., at 637 (2006). This view has more recently been contested by G.W. Dent, Jr., 'The Essential Unity of Shareholders and the Myth of Investor Short-Termism', 35 Del. J. Corp. L. 1, at 97 (2010).

30. See, e.g., L.E. Strine, Jr., 'One Fundamental Corporate Governance Question We Face: Can Corporations Be Managed for the Long Term Unless Their Powerful Electorates Also Act and Think Long Term?', 66 Business Lawyer 4, at 3 (2010); See also A. Rappaport, 'Ten Ways to Create Shareholder Value', 84 Harvard Business Review 9, at 66-76 (2006) (arguing that acquisitions should be made that maximize expected value even at the expense of lowering near-term earnings, and that directors should be rewarded for delivering superior long-term returns). impact on the short term due to pressures from shareholders ${ }^{31}$ to deliver high share prices and dividends and peer pressure from competitors in financial markets as well as executive remuneration and compensation schemes $^{32}$ linked to current profitability. (3) The strategy of long-term decision making remains to have its weaknesses as it does not necessarily guarantee more beneficial results for the performance of the company than the short-term horizon. In essence, bad decisions come from bad ideas ${ }^{33}$ or bad motives - e.g. opportunistic behaviour during conflicts of interests - irrespective of their time horizon. The time horizon merely indicates the time span of the consequences of good or bad decisions. For example, imagine the worst case scenario where a defective long-term perspective results in disastrous ex post long-term financial consequences because of poor ex ante long-term business strategies. ${ }^{34}$

Short-term objectives enable the pursuit of long-term goals. Directors continuously need to balance such interim short-term objectives with strategic long-term goals $^{35}$ because both carry risks that are interwoven. With every decision, directors are confronted with the dilemma to not let short-termism prevail at the expense of long-termism and vice versa. Therefore, it is questionable whether there is a need to include the longterm perspective explicitly when defining the directors' duty to act in the interest of the company while shortterm dynamics also play an important role in practice.

The indeterminate legal underpinnings of the Dutch stakeholder model are also subject to criticism from directors. Even before the financial crisis, former DSM board director Peter Elverding had been quoted saying that the Dutch principle of stakeholderism can be defined as a form of hypocrisy. ${ }^{36}$ Elverding believed the hypocrisy lied in the fact that directors are required to consider a wide range of interests according to the law while they are not able to voice the value of these interests. He stated that, on that account, the view to always express all values in the form of money dominates in practice. It seems that the essence of Elverding's argument comes down to the fact that non-financial interests are difficult to deal with as they cannot be quantified whereas shareholders' interests might be more easily translated into the quantifiable factor of shareholder value. Indeed, it may not seem feasible for directors to obey the legal directors' duty to act in the interest of the company and its affiliated enterprise as they cannot assess the values

31. Strine (2010), above n. 30; De la Rosière (2009), Report on the future of financial supervision in the EU, 25 February 2009, at 10.

32. R.S. Thomas \& J.G. Hill (eds.), Research Handbook on Executive Pay (2012), at 232-233; Rosière (2009), above n. 31, at 10, 30-31.

33. See J. Kay, The Kay Review of UK Equity Markets and Long-term Decision Making (2012), at 10.

34. See, e.g., Knowledge@Wharton, What's Wrong with This Picture: Kodak's 30-year Slide into Bankruptcy, available at: <http://knowledge .wharton .upenn .edu/ article.cfm ?articleid=2935> (last visited 14 Oct. 2013) (describing Kodak's downfall resulting from a failure to adapt its long-term business strategy to the innovative technological changes in modern times).

35. A. Keay, The Corporate Objective (2011), at 53-54.

36. S.M. Bartman (2007), De verweesde onderneming (The Orphaned Enterprise), Ondernemingsrecht, at 316-319 (2007-2008). 
of a wide range of stakeholders' interests in practice. ${ }^{37}$ Additionally, because directors remain to have wide discretionary powers, the influences of extra-legal indicators and internal pressures such as corporate culture and shareholder power are also reinforced and may result in directors departing from the stakeholder model. Consequently, an ineluctable gap between the theory and practice of the Dutch stakeholder model continues to exist.

\subsection{Towards a Specification of Open-Textured Directors' Duties}

The main drawback of existing directors' duties seems to be that they are perceived as isles of law girt with contingencies in theory and practice because of their open-textured formulation. These duties have evolved into somewhat nebulous legal formulas with an indicative character merely setting out minimum requirements for directors. Yet the capacious language of these duties can be justified by the fact that they are designed to cover various circumstances as directors have a broad responsibility to manage the overall business and affairs of the company. Against this background, legal directors' duties merely serve as a safety net to accommodate and secure general precepts rather than to enclose all potential particularities within a cobweb of detailed commandments to span all-embracing rules in which directors might become entangled.

The question then is why the various situations and circumstances that are covered by the open-textured directors' duties are not elaborated upon doctrinally to dismantle the ambiguity. By doing so, we may come up with a variety of consistent and coherent interpretations of directors' duties tailored to various contexts. The current lack of recognition of context-specific directors' duties on a doctrinal basis sustains the ambiguity of these legal standards of conduct and hinders a more substantive formulation of the contents of directors' duties. Such legal uncertainty also results in poor enforcement mechanisms which on their turn eventually effectuate deficiencies in directors' accountability. Consequently, the next paragraphs view the question whether there is a need and rationale (Section 3) as well as a potential (Section 4) to specify the contents of directors' duties in the context of banks aligned with enforcement mechanisms (Section 5) in order to enhance the accountability of directors in the banking sector.

Other factors, such as the reputation and the perception of individual performance of directors may also cause directors to operate the enterprise in a manner that maximizes financial performance indicators, including shareholder returns, see C. M. Daily, D. R. Dalton \& A. A. Cannella Jr, 'Corporate Governance: Decades of Dialogue and Data', 28 Academy of Management Review 3, at 371-382, 373 (2003).

\section{The Need and Rationale for Context-Specific Directors' Duties in the Banking Sector}

In the post-crisis developments and calls for legal reform, chiefly two legal strategies come to the forefront, both entailing a proposition to shift the scope of the contents of the directors' duties in the banking sector. The first strategy zooms in on the protection of the clients' interests in their capacity of key stakeholders in the banking sector recognizing that directors have duties towards those for whom they hold funds in trust, besides shareholders. The second strategy is concerned with expanding the focus of directors' duties in the banking sector towards the public interest. When taking these strategies into account, directors of companies in the banking sector would be subject to stricter legal duties in comparison to directors of non-financial companies. Thus, these reform strategies can be regarded as proposals, which factually attempt to flesh out sectorspecific directors' duties in the context of the banking sector. Firstly, this paragraph provides a comparative review of the post-crisis proposals for reform aimed towards context-specific directors' duties towards clients' interests in the Netherlands, the United Kingdom and on a European level. Secondly, the social function of banks will be scrutinized to view the need and rationale for shifting the scope of directors' duties in the banking sector towards the public interest.

\subsection{Post-Crisis Calls for Legal Reforms: Shifting} the Scope Towards Clients' Interests

In several countries, there have been calls for legal reform of directors' duties towards clients' interests - in their capacity of key stakeholders - in the aftermath of the financial crisis. In the followings sub-paragraphs, I provide a comparative analysis of the various proposals for reform to assess the various arguments pro and con of such a shift.

\subsubsection{The Netherlands}

As a direct consequence of the financial crisis, there has been specific attention for reforms in the corporate governance of banks in the Netherlands. Areas for reform have been brought in the limelight by the Dutch Central Bank and the Advisory Committee of the Future of Banks in the Netherlands ${ }^{38}$ both stressing the point that the strategy of financial institutions has to be redefined into one where the focus is once again on customers and where the institution is independent of its market value. It is mentioned that the focus on clients' interests will at the same time benefit the interests of other stakeholders such as employees and shareholders. Tangible solutions in alliance with banks are pursued in the semi-legal environment with the implementation of best practices

38. Advisory Committee on the Future of Banks in the Netherlands (2009). Restoring trust, 7 April 2009, at 2. 
in newly introduced sector-specific corporate governance codes.

In April 2009, the Advisory Committee on the Future of Banks issued the report Restoring Trust to come up with recommendations for the future of governance in the banking sector. Consequently, the Netherlands' Bankers Association published the Banking Code (Code Banken) in September 2009; a corporate governance code for banks. ${ }^{39}$ The Banking Code has to be read in concert with the full set of national, European and international laws, regulations, codes and jurisprudence. This code has a self-regulatory character to a certain degree as it is based on the comply-or-explain principle. The complyor-explain principle requires banks to include a statement in their annual report clarifying to what extent they have acted in compliance with the principles and to provide an explanation when a principle is not applied. The Banking Code came into force on 1 January 2010. The code encompasses a specific duty of care towards clients. This notion is laid down more specific in paragraphs 3.2.1 and 3.2.2 of the Banking Code both mentioning obligations of stakeholder consideration for bank directors in their tasks and working methods.

Paragraph 3.2.1 of the Banking Code postulates that the bank's executive board shall ensure that it carefully considers the interests of all of the parties involved in the bank, such as the bank's clients, its shareholders and its employees, in all of its actions. These considerations shall take into account the continuity of the bank, the environment and society in which the bank operates as well as legislation, regulations and codes that apply to the bank. Paragraph 3.2.2 of the Banking Code states that maintaining a continued focus on its clients' interests is a necessary precondition for the continuity of the bank. Clients should in any case be treated with due care and directors should see to it that the duty of care for the client is embedded in the bank's culture.

In December 2010, the Dutch Association of Insurers followed suit in a similar manner by publishing its Governance Principles based on the Banking Code. The Governance Principles took effect on 1 January 2011 on a similar comply-or-explain basis. ${ }^{40}$ It is stated that an insurers' board of directors has a responsibility for the balanced trade-off of interests of all parties involved with the insurer such as its clients, shareholders and employees. In doing so, the continuity of the insurance company, the social environment in which the insurance company operates and the applicable laws, rules and codes have to be taken into consideration. ${ }^{41}$ Moreover, clients should be treated with care at all times.

39. The Code is available at: <http://www.nvb.nl/scrivo/asset.php? id=534018 > (last visited 24 June 2012). The Banking Code applies to all activities performed by banks in possession of a banking license granted under the Financial Supervisory Act $(W f t)$. The Banking Code includes principles complementary to the Dutch Corporate Governance Code of December 2008 applied by listed banks and often applied by non-listed banks on a voluntary basis.

40. The Governance Principles apply to all activities performed by insurance companies in possession of a license granted under the Financial Supervisory Act (Wft).

41. Para. 3.2.1 Governance Principles.
The legal impact of reforms through the Banking Code

In general, best practices are to be considered by directors in the form of extra-legal standards of conduct to foster aspirational ideals for good corporate governance. The main advantages of corporate governance codes enshrined with such best practices are that they are more flexible than statutory laws, they are often designed in extensive consultation with the business sector guided by the sector's expertise, and they upkeep the discretionary powers of directors. Yet at the same time, a major disadvantage of these codes may be implicit in the latter argument: companies are able to design their own standards of conduct without directors being subject to an external accountability mechanism. In the Netherlands, this issue has been resolved to certain extent as it is accepted that the Dutch Corporate Governance Code with its best practices may be taken into account by courts for the interpretation of legal directors' duties. ${ }^{42}$ Thus, courts have to certain extent strengthened the legal enforcement of best practices in this code. It is arguable that other corporate governance codes such as the Banking Code might also be interpreted in this manner and that its sector-specific best practices may be legally reinforced despite a lack of legal implementation.

\subsubsection{The United Kingdom}

In the United Kingdom, Sir David Walker chaired a post-crisis review of corporate governance in the banking industry - commissioned by the UK government resulting in recommendations in the 2009 Walker Reviem. ${ }^{43}$ One of the criteria given priority in the Walker Review was the development of proposals for best practice, which would add value over time to the benefit of shareholders, other stakeholders and for society more widely. ${ }^{44}$ During the consultation phase, there had been made suggestions to broaden directors' duties within banks and financial institutions to take the interests of a wide range of stakeholders into account more explicitly within the decision-making procedure. However, the Walker Review concluded this would bring no advantage, yet rather potentially negative consequences. The rationale behind the negative outcome to the proposal for an extended duty is that conflicts between shareholders' interests and stakeholders' interests are often complex and already recognized within the current $\mathrm{UK}$ regulatory framework.

In the United Kingdom, the law provides that directors have the duty to promote the success of the company. ${ }^{45}$

42. Dutch Supreme Court 9 July 2010, NJ 2010, 544 (ASMI). See also A.F. Verdam, 'De zorgplicht van de bestuurder van een rechtspersoon' (The Duty of Care of a Corporate Director), 18 Onderneming \& Financiering 2, at 105 (2010). NB: The Dutch Corporate Governance Code only applies to listed companies.

43. Walker Review (2009), A review of corporate governance in UK banks and other financial institutions: final recommendations, available at: <http://webarchive.nationalarchives.gov.uk/+/http://www.hm-treasury.gov.uk/d/walker_review_261109.pdf> (last visited 14 June 2012).

44. Para. 1.25 Walker Review.

45. Sec. 172 UK Companies Act 2006. 
The scope of this directors' duty recognizes shareholders' interests in a more clean-cut manner as the UK government has explicitly stated this duty represents the enlightened shareholder value principle during the major revision of the UK Companies Act in 2006. In the UK government White Paper ahead of the major company law reform, it was concluded,

The statement of duties will be drafted in a way which reflects modern business needs and wider expectations of responsible business behaviour. The CLR (Company Law Review, WK) proposed that the basic goal for directors should be the success of the company for the benefit of its members as a whole; but that, to reach this goal, directors would need to take a properly balanced view of the implications of decisions over time and foster effective relationships with employees, customers and suppliers, and in the community more widely. The Government strongly agrees that this approach, which the CLR called 'enlightened shareholder value', is most likely to drive long-term company performance and maximise overall competitiveness and wealth and welfare for all. ${ }^{46}$

Similar to the Dutch approach, this duty to act for the success of the company encompasses stakeholders' interests. Yet the consideration of stakeholders' interests is regarded as the justified means to ultimately obtain the objective of the success of the company for the benefit of the shareholder body.

The Walker Review comments that diluting the primacy of the duty of directors of bank and other financial institutions to shareholders in order to accommodate a new accountability to other stakeholders would risk changing the contractual and legal basis on which the UK market economy operates fundamentally. Moreover, it would introduce potentially substantial new uncertainty for shareholders as to the value of their holdings and would be likely to lead to shareholder exodus from the sector and a rise in the cost of capital for banks and other financial institutions. ${ }^{47}$

In summary, above-mentioned post-crisis proposals for legal reform have developed differently in both countries. In the United Kingdom, the possibility of sectorspecific directors' duties in the context of banks and other financial institutions has been explored but rejected as the reform may have consequences to the detriment of shareholders' interests. In the Netherlands, reforms for context-specific directors' duties in the banking sector include a greater emphasis towards clients' interests and thus the contents of the standards of conduct are expanded and more specified for directors of banks as opposed to other types of companies. Although the Dutch solution has a semi-legal character based on a self-regulatory corporate governance code with attention to the implications of extra-legal indica46. UK Department of Trade and Industry (DTI), Company Law Reform Bill
- White Paper, DTI: London 2005, at 20-21.

47. Walker Review (2009), above n. 43, at 137 tors, it can be argued that its best practices may be reinforced in courts.

\subsubsection{Europe}

In June 2010, the European Commission adopted a green paper launching a public consultation on ways to improve corporate governance mechanisms in financial institutions in order to prevent future crises. ${ }^{48}$ Among other topics, the question was raised whether there is a need for creation of a specific duty - 'duty of care' - to be established for the board of directors. This duty would then require directors of financial institutions to take the interests of depositors and other stakeholders into account during the decision-making procedure. ${ }^{49}$ Subsequently, this duty would help encourage the board of directors to adopt less risky strategies and improve the quality of the financial institution's long-term risk management. The green paper did mention the fact that this idea might be hard to realize as there exist diverging legal frameworks in Europe that would have to be examined and adapted in order to take away limitations. On the other hand, similar provisions with obligations regarding conduct towards clients already exist within the EU regulatory framework on the level of certain financial institutions. For example, an investment firm situated in one of the EU Member States already has a duty within to 'act honestly, fairly, and professionally in accordance with the best interests of its clients' ${ }^{50}$ when providing investment services.

\section{Responses to the proposal}

In response to this consultation, a large majority of the respondents stated that they would not favour the creation of a specific duty of care with regard to specific stakeholders because they considered the primary fiduciary duty of directors to be to their shareholders. ${ }^{51}$ The range of objections towards the new duty - coming from a large number of organisations sceptical about the introduction of the proposed 'duty of care' into European legislation - widely differed predominantly according to the following arguments:

\section{a. Directors have a priority to their shareholders.}

Directors represent the interests of the shareholder body and the interests of depositors and policy holders, respectively, should not be singled out specifically beyond having regard to the interests of the financial institution itself and the ones of all other stakeholders. The role of directors and regulators needs to be clearly defined in that there should be a clear distinction between the role of directors achieving corporate success and regulators protecting public interest. Directors

48. European Commission (2010), above n. 3

49. P.O. Mülbert, 'Corporate Governance of Banks', 10 European Business Organization Law Review 3, at 411-436, 434 (2009).

50. Art. 19 Directive 2004/39/EC.

51. The responses of individuals, public authorities and registered organisations I have consulted as sources for this analysis are all available at: <https:// circabc .europa .eu/ faces/ jsp/ extension/ wai/ navigation/ container.jsp> (last visited 14 Oct. 2013). 
should have regard to other stakeholder groups (such as communities and employees), but they must primarily remain focused on the long-term interests of the company and its shareholders. It would not be justified to explicitly highlight particular interests, and it would also establish a random order of priority of these interests.

b. Obligations to customers' and other stakeholders' interests already exist and are sufficiently addressed by other legislation.

Directors already consider the interests and the implications of other stakeholders as part of their existing decision-making procedures while discharging their duties as a good practice in systemically important financial institutions. It is argued that directors have the overall responsibility for the institution in any event and must take decisions in the best interests of the company. Except when a firm is approaching the zone of insolvency, the primary duty of directors should be to the company and its shareholders. This responsibility includes all stakeholders, and there is no value of singling out the interests of one group in a prescriptive manner, as such an obligation could potentially have the result of causing a conflict of interest within the institution. The interests of depositors and other creditors are protected by enhanced capital requirements and tighter regulation on risk management and deposit guarantee schemes as set out in the Capital Requirements Directive.

\section{c. The creation of a nem duty could have negative effects in practice.}

A distinction should be made between a general responsibility on directors to take into account wider stakeholders in considering the interests of the company and a specific duty of care to persons other than the company itself and/or its shareholders. Changing the persons to whom directors owe a duty could create considerable difficulties and unintended consequences. There should be caution to the effects of imposing a standardized approach on financial institutions or deterrence of the taking of risk. The creation of a new legal obligation would be too general and have litigation consequences that are difficult to measure. The implementation would trigger many practical difficulties, the main one being the prioritisation of duties. A second difficulty would be to identify all existing and potential conflicts of interest among stakeholders and to manage such conflicts of interest. Directors then would have to conduct deeper research prior to any decision.

d. There is no one-size-fits-all solution possible on a European level.

It depends on national corporate and financial law systems how and in what manner it would be achieved that directors take the interests of depositors and other creditors into account in their decision making, in addition to shareholders' interests.
A closer look at the above-mentioned drawbacks mentioned by the respondents reveals contradictory understandings. A few respondents focus on the practical difficulties that would arise with the implementation of new duty of care towards stakeholders such as the definition and prioritisation of stakeholders' interests while others refuse to acknowledge the sheer possibility of such a trade-off because the primary duty of directors is thought to be to shareholders. However, there seems to be a general agreement that directors should act in the best interest of the financial institution. ${ }^{52}$ The following responses by the Dutch government and the UK supervisory bodies reveal that a legal duty to act in best interests of the company already exists in the Netherlands and the United Kingdom but there is a difference in the interpretation of the contents of this duty.

The Netherlands: Response from the Dutch government

The Dutch government stated to be in favour of a general duty of care in its response to the consultation by explaining that this measure would be in line with the existing concept of corporate governance in the Netherlands. The main principle behind this concept is that a company is a long-term alliance between the various parties involved in it. It was stated that directors already have an overall responsibility for weighing up the interests of the various stakeholders in order to guarantee the continuity of the company. ${ }^{53}$ Although the Dutch government did not mention the introduction of the Banking Code, this code also emphasizes a duty of due care owed to clients by means of good practice in Dutch banks.

The United Kingdom: Responses from the Financial Reporting Council and Financial Services Authority

In the United Kingdom, the public authorities Financial Reporting Council (FRC) and Financial Services Authority (FSA) submitted a response to deliver a standpoint from the governmental point of view regarding the corporate governance system in the United Kingdom. ${ }^{54}$ The governance debate in the United Kingdom is centred around the long-term view in the UK Companies Act 2006, which requires directors to focus on enlightened shareholder value. According to legal requirements, directors are considered to be stewards of shareholders' interests while they are additionally

52. European Commission (2010). Feedback statement: Summary of responses to Commission Green Paper on corporate governance in financial institutions, Brussels: European Commission 2010, at 11.

53. Dutch Ministry of Finance (2010). Consultatiereactie Groenboek Corporate Governance (Consultation Response to Green Paper on Corporate Governance), Kamerstukken II 2009-2010, 21 501-07, nr. 752 (attachment), at 2. This definition is similar to the one mentioned in the Dutch Corporate Governance Code, Preamble, No. 7.

54. FRC (2010), Financial Reporting Council Response to the EU Commission's Green Paper on Corporate Governance in Financial Institutions and Remuneration Policies, 2010; FSA (2010), Financial Services Authority (FSA) Response to Commission Green Paper: Corporate Governance in Financial Institutions and Remuneration Policies, 31 August 2010. 
required to pay attention to the community, environment, employees and other standards relevant to the success of the company. ${ }^{55}$ The FSA mentions that it already imposes a requirement on the companies it regulates to pay due regard to the interests of customers and treat them fairly. ${ }^{56}$ Yet directors are merely accountable to shareholders if they do not comply with the law. The accountability towards shareholders shall not be applied to enforce directors to act for the success of the company beyond shareholders' interests, e.g. customers' interests. The FRC maintains that shareholder control needs to be retained as shareholders deliver new capital. ${ }^{57}$ It is also for this reason that the FRC disagrees with the recommendation to impose a specific duty of care towards other stakeholders. ${ }^{58}$ Another objection to the duty is raised by the FSA stating that there should be given careful thought as to who is included under the heading of 'other stakeholders' before introducing this requirement to directors. Furthermore, the FSA questions how directors are expected to resolve any conflicts that arise in the interests of shareholders, customers and 'other stakeholders'. 59

In summary, the responses to the European consultation for the creation of a sector-specific duty of care towards clients' interests in financial institutions are varied, and there is no agreement on a European level because of diverging domestic corporate governance systems. In the Netherlands, a positive attitude towards such a duty prevails because this measure is in line with the existing concept of governance, where directors are required to take a wide range of stakeholders' interests into account for the continuity of the company. Yet in the United Kingdom, where directors may also take a range of stakeholders' interests into account, the primary responsibility nonetheless seems to be towards shareholders' interests in the end and therefore a specific duty with an emphasis on clients' interests is not favoured.

\subsection{Post-crisis Developments: Shifting the Scope} Towards the Public Interest

\subsubsection{Risk Management in the Banking Sector: Public Costs and Public Benefits}

When we view the significant position of banks in society, some specific features ${ }^{60}$ can be noticed that set the banking sector apart from other lines of business. Mostly, these specific features are connected with the fact that commercial business activities of banks are significantly engaged with risk management to guard the impact on public costs and benefits. Failures in the governance of banks lead to major public costs. The other

55. FRC (2010), above n. 54, at 2; Sec. 172 Companies Act 2006.

56. Principle 6 , Business Principles, FSA Handbook, available online at: <http://fsahandbook.info/FSA/html/handbook/PRIN/2/1> (last visited 14 Oct. 2013).

57. FRC (2010), above n. 54, at 3 .

58. FRC (2010), above n. 54, at 5.

59. FSA (2010), above n. 54, at 6.

60. G. Ferrarini \& M.C. Ungureanu, Unique Features in the Governance of Bankers' Compensation (2009), in Liber Amicorum in Honour of Theo Raaijmakers, at 123 side of the picture is the impact on public benefits by viewing the societal function of banks to secure the public good of financial stability. Looking at the public costs and benefits, it becomes clear that the balance between the costs that come with risk and the benefits that come with returns has wide implications for the public interest.

For banks, the far-reaching consequences of their actions on the public interest bring along the duty to deal in a prudent manner with the funds entrusted to them even next to their existing legal and public obligations. ${ }^{61}$ Yet in the aftermath of the recent financial crisis, it has often been argued that banks and other financial institutions have lost track of their social significance during the past years. They are alleged to have subordinated the interests of employees, customers and society and the continuity of the enterprise to shortterm profits and shareholders' interests. ${ }^{62}$ The business decisions made by bank directors, which led to this situation, have played an important role in this matter. In an earlier essay, I have stressed that the main peril of a corporate environment where directors merely zoom in on shareholders' interests is that social values will be neglected and swapped for sheer economic values. ${ }^{63}$ The following sub-paragraphs further examine the public costs and public benefits of their business activities to highlight the social context of banks.

\subsubsection{Public Costs: Bailouts, Moral Hazard and Excessive Risk-Taking}

According to the free market discipline, companies with poor results and poor (risk) management, which are eventually confronted with fatal economic troubles, are essentially forced to bear their losses and to settle with the devastating consequences of a bankruptcy. As such, the free market economy draws close analogies with the Darwinian evolutionary concept of natural selection and 'survival of the fittest'. ${ }^{64}$ The free market mechanism prevents directors from taking excessive risks to the detriment of their company. Yet financial institutions may nonetheless be prone to excessive levels of risk-taking by their directors because of the creation of moral hazard as a perverse by-product of government bailouts. As we

61. See, e.g., Basel Committee on Banking Supervision (2005), Compliance and the compliance function in banks, April 2005, at 7: 'A bank should hold itself to high standards when carrying on business, and at all times strive to observe the spirit as well as the letter of the law. Failure to consider the impact of its actions on its shareholders, customers, employees and the markets may result in significant adverse publicity and reputational damage, even if no law has been broken'. See also Group of Thirty (2012), n. 4 (arguing that a large concentration of power and social externalities associated with the business of significant financial institutions underscore the critical importance of good corporate governance of such entities).

62. DNB (2009). De 7 Elementen van een Integere Cultuur: Beleidsvisie en aanpak gedrag en cultuur bij financiële ondernemingen 2010-2014 (The 7 Elements of a Sound Culture: Policy Outlook and Tackling Behavior and Culture at Financial Enterprises), November 2009.

63. W. Khan, (2011), Humanizing the law of business corporations for good management practices, 3rd Global Peter Drucker Forum, November 2011, available at SSRN: <http://ssrn.com/abstract=1992636> (last visited 14 Oct. 2013).

64. J. Wright, The Ethics of Economic Rationalism (2003), at 124 
have witnessed during the recent financial crisis, bailouts to the financial sector in the form of government interventions were provided by means of supplying loans, giving capital injections, or purchasing assets of a financial institution, or a group of financial institutions facing severe financial difficulties or bankruptcy. Bailouts have a disruptive effect as they form an exception to the free market rule ${ }^{65}$ and result in a form of subsidized risk-taking where markets are not self-correcting. The rationale behind bailouts mostly stems from the problem of 'too-big-to-fail'b6 financial institutions. When large financial institutions are confronted with failure, there are huge risks of a domino effect of failures being triggered in other companies doing business with the failed institution. Bailouts are precautionary measures aimed at preventing the downfall of such vulnerable financial institutions. Governments are not equipped with a clear-cut rule they might apply in order to decide when to step in and to intervene by means of bailouts. ${ }^{67}$ In terms of economic efficiency, it is plausible that the government will come to the rescue when the costs of non-intervention are estimated to be higher than the decision to intervene but it is difficult to make such a cost-benefits analysis. When too large institutions fail and governments decide not to bail out, there is the risk that the financial troubles will be dispersed on an unforeseeable macro-level and that the national economy collapses as a whole. Moreover, the contagious effects are not bound to geographical limits and could spread to other countries thereby negatively affecting international financial markets. Shareholders and a wide range of other stakeholders are benefited if the company remains to be a going concern, preventing a financial meltdown and a massive increase in unemployment figures. Consequently, governments are forced to interfere and to spend public funding to prevent the failure of such too-big-to-fail financial institutions. Factually, governments step up and take over the institutions' responsibilities towards shareholders, employees and creditors of the institution and the society as a whole. In the political-economic discourse, it has been argued that the bailouts in the recent financial crisis have contributed to the privatization of profits and the socialization of losses. ${ }^{68}$

The creation of moral hazard by means of government bailouts leads to perverse effects in risk management by inducing directors of financial institutions to take undue risks because the costs associated with those risks will

65. See, e.g., B. Ritholtz, Bailout Nation (2009), at 161 et seq.; G.H. Stern \& R.J. Feldman, Too Big to Fail: The Hazards of Bank Bailouts (2004); K. Dowd, 'Moral Hazard and the Financial Crisis', 29 Cato Journal 1, at 141-166 (2009).

66. Synonyms used are (inter alia) 'too interconnected to fail', 'too complex to fail, 'too important to fail' and 'too international to fail'.

67. See, e.g., V. McKinley \& G. Gegenheimer (2009), Bright Lines and Bailouts: To Bail or Not To Bail, That Is the Question, Policy Analysis, No. 637.

68. E. Engelen, et al., After the Great Complacence: Financial Crisis and the Politics of Reform (2011), at 32; N.N. Taleb, 'Ten Principles for a Black Swan-proof World', Financial Times (2009), 7 April 2009; J.E. Stiglitz, 'Obama's Ersatz Capitalism', New York Times, 31 March 2009. not be directly borne by their companies. This implies that financial institutions supported by government protection are less vulnerable for economic uncertainty and may even seek to benefit from their preferential position by taking excessive and immoral risks as they are aware of their ability to rely on the implicitly guaranteed governmental protection mechanism. Such a situation incentivizes harmful risk-taking and provides too-bigto-fail financial institutions with competitive advantages over other players in financial markets. Several regulatory measures have already been taken to curb the lack of market discipline and to enhance the risk-management framework of banks and other financial institutions. For example, standards on capital adequacy have been tightened with the implementation of Basel $\mathrm{III}^{69}$ in order to strengthen the solvency of banks. This measure does not directly affect the responsibility of directors in decisionmaking procedures in order to eliminate the problem of moral hazard but rather shifts the allocation of risk burdens to shareholders by extending the liability of shareholders with a greater amount of capital.

\subsubsection{Public Benefits: Public Utility Function}

When large business corporations become insolvent, their assets can be sold or liquidated and other valuecreating business corporations may take their place in a process Schumpeter has described as 'creative destruction'. ${ }^{70}$ Yet financial institutions have a public utility function - even though they are private actors and not public institutions - because of their central role in financial intermediation and capital allocation, and when they take risks, they have to take the public interest into account because of their systemic function in the economy. ${ }^{71}$ The banking sector has a significant role in providing capital to companies and individuals serving the needs of the society and the economy. The public utility function of the banking sector becomes apparent when taking into account that the public interest is at stake in case failures occur at large banks as this may cause a breakdown in economic activity ${ }^{72}$ and threaten the financial stability as a whole.

In summary, banks are subject to different conditions than ordinary business companies are because of the major public costs and benefits they have to take into account in their risk management. The recent financial crisis has revealed this notion all the more. Because of this distinct position, the need for a context-specific approach for directors' duties in the banking sector

69. Basel Committee on Banking Supervision (2010), Basel III: A global regulatory framework for more resilient banks and banking systems, Basel: BIS 2010. Also available online at: <http://www.bis.org/publ/ bcbs189.pdf> (last visited 14 Oct. 2013).

70. J.A. Schumpeter, Capitalism, Socialism and Democracy (3rd ed.) (1950).

71. See also A. Kaletsky, Capitalism 4.0: The Birth of a New Economy in the Aftermath of Crisis (2010), at 250: 'Banks may be legally structured as private companies, answerable only to their shareholders, but they have a uniquely important social function and thus operate in the public realm, with implicit government support.'

72. Such is also the case with other financial institutions, see V.V. Acharya, et al., Guaranteed to Fail: Fannie Mae, Freddie Mac, and the Debacle of Mortgage Finance (2011), at 65. 
whereby the public interest is taken into account more significantly is justifiable.

\section{The Potential for Context- Specific Directors' Duties and Enforcement Mechanisms in the Banking Sector}

When evaluating the feasibility for context-specific directors' duties, it is essential to examine the potential for such duties from the view of law, besides the need and rationale for reforms. In this paragraph, the potential for context-specific directors' duties in the banking sector will be examined by viewing how courts may create and apply doctrines to formulate the context-specific contents of open-textured directors' duties. In the context of the banking sector, courts may develop contextspecific duties that require directors to take the public interest into account. In order to accommodate an increased accountability of directors' duties towards the public interest, there is a justified need for the introduction of public-enforcement mechanisms but the question is whether the introduction of such enforcement mechanisms is feasible.

\subsection{Context versus Doctrine in the Creation of Law}

Corporate law systems have adopted open-textured standards when it comes to directors' duties in order to deal with the question how to balance general standards with individual circumstances ${ }^{73}$ in a just manner. ${ }^{74}$ In practice, tensions arise when it comes to judicial review of open-textured directors' duties because these standards of conduct are caught in an interdependent relationship of context and doctrine. ${ }^{75}$ On the one hand, there needs to be room for individual contextualism to apply a circumstantial interpretation of the facts against the background of an open-textured formulation.

73. 'General propositions do not decide concrete cases.' Lochner v. New York (1905) 198 US 45 (O.W. Holmes, Jr.'s diss. opinion).

74. More in general, all legal systems are concerned with the question how to find a balance between doctrine and contextualism by means of rules and standards, see H.L.A. Hart, The Concept of Law (3rd ed.) (2012), at 130: 'In fact all systems, in different ways, compromise between two social needs: the need for certain rules which can cover great areas of conduct, safely be applied by private individuals to themselves without fresh official guidance or weighing up of social issues, and the need to leave open, for later settlement by an informed, official choice, issues which can only be properly appreciated and settled when they arise in a concrete case.'

75. Assink identifies this tension in matters of director liability (Sec. 2:9 Dutch Civil Code) and calls for increased doctrinal conceptualization to create 'a more balanced interplay between contextualism and doctrinal conceptualization', see B.F. Assink, 'Internal and External Director Liability in Dutch Corporate (Case) Law - Towards a More Balanced Interplay Between Contextualism and Doctrinal Conceptualization (or simply: Why Doctrine Matters, Besides Context)', in Corporate Bona Fides in Corporate and Securities Law (2013) (forthcoming).
Courts recognize that directors may have to act and decide differently from one context to another in order to fulfil their directors' duties. On the other hand, any judicial interpretation of directors' duties should occur against the background of an organised bulk of relevant previous jurisprudence. Context allows change whereas doctrine provides continuity. It is difficult to find a refined balance in the delicate duel between these two significant law-making concepts. With the desirability of a solid evolution of corporate law - and more specific a consistent future evolution of directors' duties - in mind, it is readily agreeable to steer towards calls for an increased doctrinal approach of such contexts to be developed by courts with the argument that it must not just be about fact, but also about a balanced system with a coherent rationale'. ${ }^{76}$

If we incorporate the concept of an increased doctrinal approach to the realm of open-textured directors' duties, this would imply that individual context-sensitive cases should be framed to a judicially developed doctrine behind a recurring set of circumstances. Relevant recurring sets of circumstances might include certain characteristics of the company - e.g. the size, type and form of the company - or certain conditions - e.g. flotations, mergers, takeovers or insolvency as part of the company's lifecycle - in which the company is situated. In the United States, such an approach already exists to certain extent where Delaware - a favoured state for incorporation of companies serving as a 'legal home' for many business entities - courts have developed adverse spectrum of doctrinal categories in jurisprudence representing a context-specific application of existing traditional fiduciary duties emphasizing that in specific contexts directors must consistently discharge their duties with a specific corporate objective while serving specific interests. ${ }^{77}$ For example, Delaware courts have articulated context-specific doctrines regarding directors' duties in the contexts of the sale of a

76. Assink (2013), above n. 75.

77. Sitkoff defines such context-specific duties as 'subsidiary or implementing rules' mentioning that 'the experience with recurring, common sets of facts and circumstances has led to the development of subsidiary or implementing rules regarding the application of the duties of loyalty or care to those circumstances', see R.H. Sitkoff, 'The Economic Structure of Fiduciary Law', 91 Bost. U. L. Rev., at 1039, 1044 (2011). I prefer not to use the term 'rules' in the narrow sense of well-delineated legal norms in this matter because these context-specific doctrines are still based on general evolving precepts and do not provide a clear-cut blueprint. 
company $^{78}$ and insolvency. ${ }^{79}$ In this article, I exemplify the notion of context-specific doctrines with an analysis of the type of company as a specific context by focusing on the banking sector.

\subsection{The Judicial Emergence of Context-Specific Directors' Duties}

\subsubsection{The United States}

In common law jurisdictions, judges have been endowed with discretionary powers to apply the mechanism of equity for the interpretation of directors' duties to the circumstances of the case. In the United States, it seems that courts have embraced this possibility to elaborate on the formulation of duties in the case of bank directors. Here, banks and insurance companies were the first publicly held corporations ${ }^{80}$ and it has long been recognized in jurisprudence that the directors of banks have the duty of exercising a higher degree of care and skill than do directors of ordinary companies. ${ }^{81}$ Nearly a century ago, courts decided directors of a manufacturing company were not expected to have the knowledge of a specialist as they are general advisers of the business ${ }^{82}$ while bank directors on the other hand seemed to be required to possess a certain degree of expertise. ${ }^{83}$ Even before, as early as 1901, the Indiana court in the United States ruled that bank directors have a primary duty to understand the financial condition of the bank. ${ }^{84}$ The court mentioned that this duty was owed to the shareholders, depositors and other creditors and the public. In the US federal banking regulation, federally insured depository institutions are claimed to be under a direct fiduciary duty to act in the best interests of the federal banking agencies while these agencies are viewed as guardians of federal deposit insurance funds protecting the public interest. ${ }^{85}$ The condition of 'unsafe or unsound banking practices' serves as a trigger for director liability arguably creating a higher standard of care

78. In this context, the corporate objective for directors changes to shortterm value maximization for shareholders instead of taking the long run into account, see Revlon, Inc. v. MacAndrews \& Forbes Holdings, Inc., 506 A.2d 173 (Del. 1986) and Wayne Cty. Empls.' Ret. Sys. v. Corti, 2009 WL 2219260, at*10 (Del. Ch. July 24, 2009): 'So-called Revlon duties are only a specific application of directors' traditional fiduciary duties of care and loyalty in the context of control transactions.'

79. Delaware courts have developed the so-called 'insolvency exception' articulating that the fiduciary duties of directors shift from shareholders to creditors in insolvent companies, see North American Catholic Educational Programming Foundation, Inc. v. Gheewalla, 930 A.2d 92 (Del. 2007). See alsoln re Hechinger Investment Co. of Delaware, 274 B.R. 71 (D. Del. 2002); Geyer v. Ingersoll Publications Co., 621 A.2d 784 (Del. Ch. 1992); Credit Lyonnais Bank Nederland v. Pathe Communications Corp., 1991 WL 277613 (Del. Ch. 1991).

80. D.T. Mitchell, 'Status Bound: The Twentieth Century Evolution of Directors' Liability', 5 NYU Journal of Law and Business 63, at 71 (2009).

81. Greenfield Savings Bank v. Abercrombie, 211 Mass. 252, 255, 97 N.E. 897, 899 (1912)

82. Barnes v. Andrews, 298 Fed. 614 (S.D.N.Y. 1924)

83. Williams v. McKay, 46 N. J. Eq. 25, 56, 18 A. 824 (1889); Campbell v. Watson, 62 N. J. Eq. 392, 409, 50 A. 120 (1901); Warren v. Robinson, 19 Utah 289, 59 P. 287 (1899).

84. Coddington v. Conaday, 157 Ind. 243, 61 N.E. 567 (1901)

85. L.G. Baxter, 'Fiduciary Issues in Federal Banking Regulation', 56 Law and Contemporary Problems 1, at 7 (1993). for bank directors than that imposed by the common law fiduciary duty of care. ${ }^{86}$ It is debatable whether the aforementioned cases provide more clarification, but courts have indeed recognized the specific character of banks on a consistent basis leading to a distinct interpretation of the contents of directors' duties to be applied in the context of banks in which the public interest seems to be recognized. ${ }^{87}$

\subsubsection{The Netherlands}

Most civil law jurisdictions have codified open-textured directors' duties of a non-fiduciary nature, which also provide judicial discretion for such a contextualized approach towards banks and other financial institutions. Yet, whereas courts in common law jurisdictions continuously might more readily embroider on an evolving body of jurisprudence on the basis of doctrinal precedent, courts in civil law countries mostly seem to apply a case-by-case approach whereby the open texture of statutory directors' duties is applied to the circumstances of individual cases and it seems more difficult for judges to come up with solid legal doctrines in such a system. This may limit the possibility to come up with a more consistent judge-made legal framework for context-specific directors' duties in order to set a precedent to be used in future cases. In the context of banks, the Dutch Supreme Court has ruled that banks have a duty of a care towards clients' interests mentioning that 'the social function of the bank involves a special duty of care, towards clients on account of their existent contractual relationship as well as towards third parties whose interests they ought to take into account according to what befits unwritten law in society. The scope of this duty of care depends on the circumstances of the case. ${ }^{\text {} 88}$ Yet courts did not elaborate on specific duties of directors in such specific contexts. In a recent judgment of the Enterprise Chamber of the Amsterdam Court of Appeal regarding the Fortis bank, the court finally seemed to acknowledge that the specific context of certain financial institutions may shift the scope of directors' duties.

86. H.M. Schooner, 'Fiduciary Duties' Demanding Cousin: Bank Director Liability for Unsafe or Unsound Banking Practices', 63 Geo. Wash. L. Rev. 175 (1995). See also R.B. Adams, 'Governance and the Financial Crisis', ECGI - Finance Working Paper No. 248/2009(2009), available at SSRN: <http://ssrn.com/abstract=1398583> (last visited 14 Oct. 2013) (arguing that regulators expect boards to act to ensure the safety and soundness of the financial institution and this is an objective that may not necessarily be in the best interest of shareholders).

87. See also S.M. Bainbridge (2013), The Fiduciary Duties of Bank Directors, 21 March 2013, available at: <http://www .professorbainbridge .com/ professorbainbridgecom/2013/03/the-fiduciary-duties-of-bankdirectors.html> (last visited 14 Oct. 2013) (arguing that there is indeed precedent to prove that the fiduciary duties of bank directors differ from the duties for ordinary corporate directors as bank directors are required to not merely consider shareholders' interests but then concluding on the contrary that this is not how the law ought to be as directors cannot serve two masters simultaneously and cannot have such 'multi-fiduciary' duties).

88. Dutch Supreme Court 9 January 1998, NJ 1999, 285 (Mees Pierson/ Ten Bos), Dutch Supreme Court 23 December 2005, NJ 2006, 289 (Safe Haven). 
In the Fortis case, ${ }^{89}$ the court reaffirmed the general duty of directors to act in the interests of the company and its affiliated enterprise and to take the interests of all stakeholders involved into account. ${ }^{90}$ The court further explained that the interests involved in this case did not only include shareholders' interests but also the interests of various clients, such as depositors. ${ }^{91}$ Furthermore, the court mentioned that the discretionary powers of directors in the management of risks are influenced by the nature of the company and the extent to which various stakeholders and - in some cases - the society as a whole have an interest in the results of its risk management. ${ }^{92}$ In this case, it was decided that due to the nature of the company - a bank - and the interests of those involved, directors were subject to a special duty of care regarding matters of risk management. ${ }^{93}$ The court also noted that the bank's duty of care is sharpened by the fact that banks in particular are dependent on the trust that clients, other (system) banks, shareholders and the public in general hold in them and undermining that essential trust would entail major and immediate risks for the functioning and thus the continuity of the bank. ${ }^{94}$ The court goes on further to mention that the Fortis bank was a system bank with a utility function in Dutch finance and economics due to the magnitude of its operations. ${ }^{95}$ The possibility that such a bank cannot fulfil its role properly under certain circumstances and the threatening downfall of such a bank carry along the risk of severe damage to the financial and economic system, according to the court. ${ }^{96}$ Interestingly, the court mentions this implies that directors should also have taken into account the general public interest which depended upon the continuity of system bank Fortis. ${ }^{97}$ As yet, the case has not been brought to the Supreme Court.

This case sets forward a context-specific directors' duty to act in the interest of the company. The duty is extended to the public interest (beneficiary) involved with the continuity (corporate objective) of Fortis as a system bank. The court has recognized the public utility function of system banks. Traditionally, the government has the duty to protect the public interest. In this case, it is rather interesting to notice that the court has acknowledged that this traditional governmental role is extended to the responsibilities of directors. Directors' duties may shift towards the public interest in the context of a system bank because of the impact of its risks and activities on the public interest.

Although this is the first case where such context-specific directors' duties are mentioned for system banks, a

89. Enterprise Chamber Amsterdam Court of Appeal, 5 April 2012 (para. 4.3), ARO 2012, 54 (VEB/Fortis)

90. $I d$

91. Id.

92. Id.

93. Id

94. Id.

95. Enterprise Chamber Amsterdam Court of Appeal, 5 April 2012 (para. 4.4), ARO 2012, 54 (VEB/Fortis)

96. Id

97. Id. doctrinal precedent may be laid for future cases if the Supreme Court upholds the decision of the Enterprise Chamber and the outcomes of this case and decides to abandon the case-by-case approach in order to apply this interpretation consistently in future cases. Admittedly, it may be a weak premise to predict a future trend of context-specific doctrines on the basis of one case, but taken together with the aforementioned post-crisis developments in the banking sector, this case exemplifies the potential to create context-specific directors' duties for the banking sector and it may very well be seen as a starting point. It must be noted that the further judicial development of such a context-specific doctrine may require many years, if not decades or perhaps another financial crisis, because courts are dependent on similarly relevant cases to be brought before them in order to elaborate on a doctrinal basis.

\subsection{The Proposal for a Legislative Emergence of Context-Specific Directors' Duties in the United Kingdom}

Besides the judicial development of context-specific directors' duties, legislators are also able to take initiative to create of context-specific directors' duties in the banking sector. Recently, the UK Parliamentary Commission on Banking Standards emphasized the importance of personal responsibility of bank directors. ${ }^{98}$ It is argued that bank directors should be held responsible for the safety and soundness of their banks. The Commission acknowledged that the obligations of directors to shareholders in accordance with the provisions of the Companies Act 2006 create a particular tension between duties to shareholders and financial safety and soundness in the case of banks. ${ }^{99}$ In order to resolve this tension, the Commission recommended a government consultation for a proposal on amending Section 172 Companies Act regarding the directors' duty to act for the success of the company in the case of banks, in order to require bank directors to prioritise the financial safety and soundness of the bank over shareholders' interests. ${ }^{100}$ Furthermore, the Commission also recommended amendments to the UK Corporate Governance Code and the PRA Principles for Businesses to reflect that bank directors are required to operate in accordance with the safety and soundness of the firm and that they need to interpret their duties in the light of this requirement. ${ }^{101}$ This standard of conduct would be somewhat similar to the one for directors of federally insured banks in the United States ${ }^{102}$ although it must be mentioned that the US standard is also accompanied with an enforcement mechanism attributed to the Federal Deposit Insurance Corporation to institute civil law

98. House of Commons (2013), Changing banking for good: Report of the Parliamentary Commission on Banking Standards, volume 1: Summary, and Conclusions, and recommendations, HC 175-1, June 2013.

99. Id., at 41

100. Id., at 42 .

101. Id., at 41-42.

102. See para. 4.2.1 
suits against former directors and officers of failed banks on the basis of detailed investigations.

\section{The Potential for Public Enforcement of Context- Specific Directors' Duties}

Enforcement mechanisms related to directors' duties provide an essential disincentive for directors to breach their duties because it makes them acutely aware that they may be held accountable. Therefore, if we want to take the potential of context-specific directors' duties in the banking sector a step further, an important subsequent question we need to think about is how such context-specific directors' duties for the benefit of the public interest may actually be enforced. Currently, the only deterrent to directors' misconduct in relation to their duties is the fear of civil liability. A breach of directors' duties gives rise to civil liability through private enforcement, but this mechanism is not primarily intended to protect the public interest. ${ }^{103}$ As such, existing sanctions from civil proceedings may not suffice to be effective for the enforcement of context-specific directors' duties towards the public interest. In the context of insolvency, civil enforcement actions are commonly brought by the liquidators of the company who may act not only in the creditors' interests but also in the public interest. Yet this mechanism does not protect the public interest outside the context of insolvency. Overall, this results in a lack of powers to take action against bank directors who fail to protect the public interest and intentionally act to the detriment of the company in breach of their context-specific duties. ${ }^{104}$

Because of the social context of banks and other financial institutions and the public interest involved as recognized by courts, it is defensible to view whether the accountability of directors regarding the above-mentioned context-specific directors' duties in the banking sector can be increased by means of public-enforcement powers. As yet, directors may be subject to secondary liability for a breach of criminal law and be confronted with criminal sanctions when an offence is committed by a company ${ }^{105}$ but there are no public-enforcement mechanisms to hold directors accountable for intentional breach of directors' duties in the public interest. In line with this need for public enforcement, recent developments in foreign jurisdictions have urged on the evaluation of a potential implementation of public-enforce-

103. This is also the case in the United Kingdom, see A. Keay (2013), The Public Enforcement of Directors' Duties, available at SSRN: <http:// ssrn.com/abstract=2201598 > (last visited 14 Oct. 2013).

104. In the United States, a similar question on how to enforce a duty to promote the public interest in corporations has arisen even outside the context of banks with the recent introduction of '(public) benefit corporations' - profit-seeking corporations that affirmatively promote the public interest -in several states.

105. Sec. 51, para. 2, Dutch Penal Code. ment mechanisms by means of increasing the role of criminal law.

\subsection{Recent Developments in Foreign Jurisdictions}

In New Zealand, proposals for a major company and securities law reform in the aftermath of the financial crisis include the suggestion to make 'the most egregious breaches of directors' duties be subject to criminal liability, and be publicly enforceable by the Financial Markets Authority and the Registrar of Companies'. ${ }^{106}$ The proposal aims to amend the Companies Act. According to the newly to be inserted section 138A in the Companies Act:

A director of a company commits an offence if the director exercises powers or performs duties as a director of the company, or omits to exercise powers or perform duties as a director of the company, -

(a) in bad faith towards the company; and

(b) believing the conduct is not in the best interests of the company; and

(c) knowing, or being reckless as to whether, the conduct will cause -

(i) serious loss to the company; or

(ii) benefit or advantage to a person who is not the company (including, for example, to the director).

However, directors will have a defence - according to the newly to be inserted section 138B of the Companies Act - if the director proves in relation to the company concerned, that the company's shareholders had given prior agreement to the relevant conduct, with the belief that the conduct was in the best interests of the company's holding company or a joint venture between its shareholders, provided that the company's constitution expressly permits directors to act in the best interests of the holding company or shareholders.

There is support for the idea of public enforcement considering the potential for substantial harm to the public interest when directors of companies in the financial sector intentionally and dishonestly breach their duties ${ }^{107}$ but this proposal is also inevitably highly con-

106. Office of the Minister of Commerce Cabinet Paper to the Chair of the Cabinet Economic Growth and Infrastructure Committee: Securities Law Reform (February 2011), available at: <http://www.med.govt.nz/ business/business-law/pdf-docs-library/current-business-law-work/ securities-law-review/review-of-securities-law-cabinet-paperfeb-2011483-kb-pdf.pdf> (last visited 14 Oct. 2013).

107. Office of the Minister of Commerce Cabinet Paper to the Chair of the Cabinet Economic Growth and Infrastructure Committee: Securities Law Reform (February 2011), at 43. The reforms in New Zealand are also in line with the existing Sec. 184 Corporations Act in Australia. In this legal provision, it is articulated that directors commit a criminal offence when they are - inter alia - reckless or intentionally dishonest, and fail to exercise their powers and discharge their duties in good faith in the best interests of the corporation or for a proper purpose. 
troversial because it would raise liability concerns for directors. ${ }^{108}$

Recently, developments have also been taking place in the United Kingdom, where the government is currently considering the possibility of introducing criminal sanctions for serious misconduct by directors in the management of a bank. ${ }^{109}$ The UK government is investigating which kind of managerial misconduct by directors of failed banks could be subjected to criminal sanctions, looking at four possibilities: (i) being a director at the relevant time of a failed bank (implying strict liability); (ii) negligence; (iii) incompetence; (iv) recklessness. This proposal would be a first step in providing publicenforcement mechanisms when directors breach their directors' duty to act for the success of the company, apart from fraud and other criminal offences such as insider dealing and making misleading statements.

These proposals for reform would have major implications for directors, shareholders and the public. Taking the discussions regarding the proposals into account, various arguments pro and con the introduction of public-enforcement mechanisms come to the forefront. ${ }^{110}$

5.2 Justifying Public-Enforcement Mechanisms While some banks may be considered 'too big to fail', they should not perceived to be 'too big to sanction' by their directors. A lack of directors' accountability to the public might decrease the public confidence in banks, especially in the aftermath of the financial crisis. Publicenforcement mechanisms bring along a fear for the stigma associated with criminal sanctions and reputational sanctions, which would deter directors from breaching the directors' duty to act in the interest of the company. This would imply a preventive effect as these mechanisms shape social norms and morals.

The need for public-enforcement mechanisms may be explained by the fact that directors currently are not always confronted with legal accountability through private-enforcement mechanisms when they breach their duty to act in the interest of the company. There may be disincentives for the company to engage in civil proceedings against directors when the costs are weighed against the benefits. ${ }^{111}$

108. For a very critical response from a US law professor to the developments regarding the criminalisation of directors' duties in New Zealand, see S.M. Bainbridge, Really Criminalizing Agency Costs, 19 October 2011, available at: <http:// www .professorbainbridge .com/ professorbainbridgecom/ 2011/10/ really -criminalizing -agency -costs .html> (last visited 14 Oct. 2013) (arguing 'this strikes me as literally insane').

109. HM Treasury (2012), Sanctions for the directors of failed banks, July 2012, available at: <https://www.gov.uk/government/uploads/system/ uploads/ attachment_data/ file/ 81565/ consult_sanctions_directors_ banks.pdf> (last visited 14 Oct. 2013).

110. For an extensive review of the various arguments in reaction to the proposals in New Zealand, see S. Watson \& R. Hirsch, 'Empty Heads, Pure Hearts: The Unintended Consequences of the Criminalisation of Directors' Duties', 17 New Zealand Business Law Quarterly 97 (2011).

111. Office of the Minister of Commerce Cabinet Paper to the Chair of the Cabinet Economic Growth and Infrastructure Committee: Securities Law Reform (February 2011), at 43. For other obstacles for the company to take action, see Keay (2013), at 7-8.
Besides the company, shareholders might hold directors accountable if they would have access to legal proceedings by means of a derivative action, but even so shareholders may lack an incentive to enforce the public interest. Shareholders' interests and the public interest are not always reconcilable. It is not to be expected of shareholders that they would hold bank directors accountable in the situation that not taking the public interest into account would amount to a breach of the directors' duty to act in the interest of the company. As such, public enforcement may also be needed to protect the public interest when shareholders are ill-equipped to hold bank directors accountable.

In addition, other stakeholders do not have access to private-enforcement mechanisms to hold directors accountable. Instead of having to rely on privateenforcement mechanisms, public-enforcement mechanisms provide a solution for proactive law enforcement when there is no party to initiate legal proceedings. With the lack of public-enforcement mechanisms, the public interest would be inadequately protected against the harm it may suffer from the breach of a bank directors' duty to act in the interest of the company in such cases.

\subsection{Obstacles to the Introduction of Public- Enforcement Mechanisms}

The introduction of public-enforcement mechanisms by means of the criminalisation of directors' duties can be considered an intrusive method to influence behaviour. It may even be called a draconian measure as there is a serious risk of exposing honest directors to uncertainty and liability as an unintended consequence. First, it would be necessary to identify clearly which directors have been in breach of their directors' duty to act in the interest of the company. There has to be established causation. This is a difficult and problematic task as it may not be clear which business decisions by which directors can be attributed to have led to an alleged breach of the directors' duty. Viewing the matter further from the directors' point of view, there would also have to be met a high threshold before action is possible ${ }^{112}$ in order to prevent that directors are chilled from taking entrepreneurial risks ${ }^{113}$ by imposing a too demanding standard of liability.

In the Netherlands, the current ambiguity regarding the directors' duty to act in the interest of the company also makes the introduction of a public-enforcement mechanism practically impossible if courts do not first provide more clarification about its scope and interpretation on a consistent doctrinal basis. Courts are hardly able to review director behaviour, which is based on an indefinite legal standard of conduct. The judiciary needs to provide a meaning of this standard of conduct on a doctrinal basis in the first place. A starting point has already been provided by the Enterprise Chamber in the afore-

112. Office of the Minister of Commerce Cabinet Paper to the Chair of the Cabinet Economic Growth and Infrastructure Committee: Securities Law Reform (February 2011), at 6.

113. Id., at 43 . 
mentioned Fortis case when it comes to system banks, which leads to the potential to develop context-specific bank directors' duties. ${ }^{114}$ The legislator could also play an important role in this matter when looking at the aforementioned proposals in the United Kingdom for a legislative emergence of context-specific directors' duties in the banking sector. ${ }^{115}$

Furthermore, it may well be that a breach of the directors' duty to act in the interest of the company shows an overlap with some form of fraudulent conduct that is already penalized with criminal sanctions in existent legislation.

High enforcement costs are another objection to the introduction of public-enforcement mechanisms. Any investigation or prosecution would be complex, timeconsuming and expensive ${ }^{116}$ and therefore might only be applied in the most serious cases where great harm is done to the public interest. ${ }^{117}$ Clear-cut parameters should be set to decide whether or not to pursue a criminal case. One should prevent a 'corporate crime lottery' 118 in which cases might be more likely brought against unpopular directors of failing banks to satisfy public outcries.

Public-enforcement mechanisms may also transform shareholders into disengaged 'free riders' as there is a risk that shareholders become more passive in monitoring the business decisions of directors and in holding directors accountable. Shareholders might assume that their interests are sufficiently taken into account by external parties by means of public-enforcement mechanisms. $^{119}$

Finally, the public should remain to be cautious and evaluate whether the proposed reforms to introduce public-enforcement mechanisms by means of criminal sanctions would be truly effective and problem solving. The public needs to assess whether such reforms are adequate enough to deal with the complexities discussed above and if they are not arbitrary and merely introduced in great haste driven by a political agenda or media pressure.

In sum, the lack of private-enforcement mechanisms to protect the public interest results in a gap that may be filled by the introduction of public-enforcement mechanisms. Public-enforcement mechanisms are a justifiable instrument to enforce context-specific duties in the banking sector because of an increased accountability of directors towards the public interest. Yet from the aforementioned obstacles, it has become clear that there are various major objections in practice that need to be overcome first before we can actually implement such measures in the near future.

\footnotetext{
114. See para. 4.2.2

115. See para. 4.3

116. HM Treasury (2012), at 13.

117. G.J. Stigler, The Optimum Enforcement of Laws (1974), at 55-67, 56, in G.S. Becker \& W.M. Landes (eds.), Essays in the Economics of Crime and Punishment, NBER (mentioning the cost limitations upon the enforcement of laws).

118. L.E. Ribstein, 'Agents Prosecuting Agents', 7 J. L. Econ. \& Pol'y 617 (2011), at 632.

119. Keay (2013), above n. 103, at 26.
}

\section{Conclusion}

The recent global financial crisis has challenged the status quo providing new opportunities to dive into a debate on reforms in the corporate governance system of the banking sector. A fruitful part of this debate may be to generate new thoughts on context-specific standards of conduct for bank directors, which may require judicial and legislative action. In the Netherlands, the statutory general directors' duty to act in the interest of the company and its affiliated enterprise requires directors to act in the interests of various corporate stakeholders involved with the pursuit of a corporate objective. Yet one of the most vented criticisms against the focus of general directors' duties towards a wide range of stakeholders' interests is that directors do not have a single metric to aim at in the pursuit of their objective and that they will eventually not be accountable to any stakeholder. ${ }^{120}$ This critique is inadequate. Due to their open-textured nature, current directors' duties are a relative concept transcending a rigid and one-size-fits-all approach in various circumstances. Context-specific duties on a doctrinal basis can provide more adequate guidance on how directors may deal with conflicting stakeholders' interests, by restricting directors' actions to the key stakeholders of the corporate objective to be pursued in the given context. For directors of banks, the introduction -specific duty for the banking sector would allow for an approach tailored to the context of an individual business industry recognizing the specific characteristics of the company. The questions we need to consider is whether there is a need, rationale and potential for such context-specific directors' duties in the banking sector. In recent post-crisis calls for reform in the Netherlands, there has been an increasing awareness of a more explicit inclusion of clients' interests in bank directors' duties through the Banking Code. Foreign jurisdictions such as the United Kingdom seem to be more hesitant to emphasize clients' interests as they recognize a primary responsibility to shareholders. Next to clients' interests, there seems to be a justified need to expand directors' duties in the banking sector towards the public interest when looking at post-crisis developments because of the major public costs and benefits of the business risks and activities of financial institutions. Expansion of directors' duties towards the public interest is a legal mechanism to create disincentives for the negative externalisation of public risks in corporate decision-making procedures by directors in the banking sector.

Besides the need and rationale, there is also a potential for context-specific duties when taking the judicial emergence and the UK proposal for a legislative emergence of context-specific directors' duties for the banking sector into account. The enhancement of the accountability of directors for such context-specific directors' duties geared towards the public interest pro-

120. M.C. Jensen, 'Value Maximization, Stakeholder Theory, and the Corporate Objective Function', 14 Journal of Applied Corporate Finance 3, at 8-21 (2001). 
vides a justified reason to introduce accommodating public-enforcement mechanisms. However, looking at the various arguments pro and con public-enforcement mechanisms, there are still many obstacles and it remains to be highly questionable whether such publicenforcement mechanisms can actually be implemented any time soon in the Dutch corporate law system. Unfortunately, the bitter implication of all this is that the introduction of context-specific directors' duties in the banking sector may as yet entail nothing more than wishful thinking as it will merely end in toothless ambitions if the lack of accompanying enforcement mechanisms remains intact.

\section{List of Cases}

\section{The Netherlands}

- Enterprise Chamber Amsterdam Court of Appeal, 5 April 2012, ARO 2012, 54 (VEB/Fortis)

- Supreme Court 9 Fuly 2010, NF 2010, 544 (ASMI)

- Supreme Court 23 Dec. 2005, N7 2006, 289 (Safe Haven)

- Supreme Court 1 March 2002, N7 2002, 296 (Zwagerman Beheer)

- Supreme Court 9 Jan. 1998, N7 1999, 285 (Mees Pierson/Ten Bos)

- Supreme Court 4 January 1963, Nf 1964, 434 (Scholten's Aardappelmeelfabrieken)

- Supreme Court 1 April 1949, N7 1949, 465 (Doetinchemse IJzergieterij)

United States

- Barnes v. Andrems, 298 Fed. 614 (S.D.N.Y. 1924)

- Greenfield Savings Bank v. Abercrombie, 211 Mass. 252, 97 N.E. 897 (1912)

- Lochner v. New York (1905) 198 US 45 (O.W. Holmes, Jr.'s diss. opinion)

- Campbell v. Watson, 62 N. J. Eq. 392, 409, 50 A. 120 (1901)

- Coddington v. Conaday, 157 Ind. 243, 61 N.E. 567 (1901)

- Warren v. Robinson, 19 Utah 289, 59 P. 287 (1899)

- Williams v. McKay, 46 N. J. Eq. 25, 18 A. 824 (1889)

Delaware (United States)

- Wayne Cty. Empls.' Ret. Sys. v. Corti, 2009 WL 2219260 (Del. Ch. July 24, 2009)

- North American Catholic Educational Programming Foundation, Inc. v. Gheemalla, 930 A.2d 92 (Del. 2007)

- In re Hechinger Investment Co. of Delaware, 274 B.R. 71 (D. Del. 2002)

- Geyer v. Ingersoll Publications Co., 621 A.2d 784 (Del. Ch. 1992)

- Credit Lyonnais Bank Nederland v. Pathe Communications Corp., 1991 WL 277613 (Del. Ch. 1991)

- Revlon, Inc. v. MacAndrems E Forbes Holdings, Inc., 506 A.2d 173 (Del. 1986) 